\section{$\$$ Research Square \\ Preprints are preliminary reports that have not undergone peer review. \\ They should not be considered conclusive, used to inform clinical practice, or referenced by the media as validated information.}

\title{
Forest succession, management and the economy under a changing climate: coupling economic and forest management models to assess impacts and adaptation options
}

\author{
Van Lantz ( $\nabla$ vlantz@unb.ca ) \\ University of New Brunswick \\ Galen McMonagle \\ University of New Brunswick \\ Chris Hennigar \\ Government of New Brunswick \\ Chinmay Sharma \\ University of New Brunswick \\ Patrick Withey \\ Saint Francis Xavier University \\ Thomas Ochuodho \\ University of Kentucky
}

Research Article

Keywords:

Posted Date: December 10th, 2021

DOI: https://doi.org/10.21203/rs.3.rs-1065616/v1

License: () (1) This work is licensed under a Creative Commons Attribution 4.0 International License. Read Full License 


\section{Abstract}

Climate change is expected to have significant impacts on forests by affecting the successional dynamics of tree species and the performance of plantations, among others. Research is needed to better understand how these factors will affect forests and economies in different regions, and how we can best adapt. To shed some light on these issues, we couple an economic (Computable General Equilibrium) model with a forest management (Woodstock) model to analyze the potential climate change impacts and adaptation options on timber supply and the economy over the 2015-95 period in a case-study province of New Brunswick, Canada. We estimate that climate change may have relatively large negative impacts on softwood timber supply (at $26 \%$ by 2095 ), softwood forestry \& logging sector output quantity (at $12 \%$ by 2095), and softwood-dependent forestry manufacturing sector output (ranging from $6 \%$ to $27 \%$ by 2095 ). Negative impacts on GDP may be relatively smaller (at up to a $0.33 \%$ reduction by 2095 ). Adapting to these climate-related changes by planting droughtresistant softwood seedlings or hardwood seedlings in place of failed softwood plantations can reduce these negative impacts. While the former adaptation option is supported using cost-benefit analysis, the latter is not - due to the large incremental costs of growing, planting, and tending hardwood seedlings. Methods developed in this study can be applied in other regions to help guide decision-making around forest management in the face of a changing climate.

\section{Introduction}

The forests of New Brunswick have provided its citizens with a source of subsistence and economic growth for centuries. Today, the forest sector harvests just over six million $\mathrm{m}^{3}$ of softwood and three million $\mathrm{m}^{3}$ of hardwood volume annually (CCFM 2020), and contributes $\$ 1.3$ billion, or $4.3 \%$, to provincial GDP (NRCan 2020). The industry also directly employs approximately 10,000 individuals within the Province (NRCan 2020).

New Brunswick's forest sector is dependent on the province's forests for its supply of timber, leaving it highly susceptible to natural and man-made disturbances such as climate change. Indeed, New Brunswick's (and Canada's) forests are already experiencing the effects of climate change. Some of the most visible effects include changes in the frequency and severity of droughts, severe winds, and damaging insect and disease attacks (Williamson et al. 2009). Other, longer term effects include changes in forest growth and succession, among others (Taylor et al. 2017). As these effects are largely expected to intensify over the next few decades, there is increasing attention being paid to the potential impacts this will have on the forest sector and the need to adapt (Lemprière et al. 2008; Taylor et al. 2017).

A number of studies have examined the biophysical and economic impacts of climate change in Canadian and/or North American forests using a variety of methods. For instance, some studies link climate change scenarios with ecological models to estimate forest productivity changes over time, and then link these with global timber market models to assess impacts on timber production, costs, and revenues in global and country-level forest sectors (for instance, see Sohngen et al. 2005, 2001; Perez-Garcia et al. 2002, 1997). Findings in these studies often reveal significant timber production and economic losses for Canadian timber producers under the various climate change scenarios. For instance, Perez-Garcia et al. (2002) estimate that Canadian timber production may decrease by as much as $4 \%$ from 2000 to 2040, and that economic losses to Canadian producers may be among the highest of all producing regions.

A few additional studies have estimated economy-wide impacts of climate change on forests and adaptation using computable general equilibrium (CGE) models (see Williamson et al. 2008; Ochuodho et al. 2012, 2016; Ochuodho \& Lantz 2014; Boccanfuso et al. 2018).[1] For instance, Williamson et al. (2008) link climate change scenarios with an ecological model to estimate forest productivity changes over time, and then link these with a CGE model to assess the economic impacts that climate change will have on a forest-dependent community in British Columbia. They find that climate change is expected to increase forest productivity and household income in the region by as much as $5 \%$. Ochuodho et al. (2012), on the other hand, use estimates of forest productivity, pest, and fire changes from the literature to assess the potential economic impacts, costs, and benefits of climate change and adaptation on Canadian provincial forests. They find a wide range of positive and negative timber production and economic impact possibilities, depending on the scenario considered. They emphasize the need to directly model the timber production impacts of climate change and adaptation using a forest management model calibrated to a specific region and use the resulting timber supply output in a CGE model to assess economic outcomes.

In this study we analyze the potential climate change impacts and adaptation on New Brunswick's timber supply and economy by coupling a forest management model with a CGE model. We focus our analysis on the effect that climate change will have on forest succession, as this has been deemed one of the most significant (and measurable) climate-induced changes predicted to occur in New Brunswick's forests over the long term (see Taylor et al. 2017). More specifically, as the climate warms, several tree species (e.g., spruce and fir) are expected to no longer naturally regenerate after harvest, while several others (e.g., tolerant hardwood and red maple) are expected to exhibit enhanced regeneration (Taylor et al. 2017). Furthermore, increased occurrence and severity of drought is expected to result in a possible failure of planted softwood stock to regenerate (Vaughan et al. 2021; Fisichelli et al. 2014; D'Orangeville et al. 2013). Within this context, we consider 4 scenarios, based on different assumptions regarding the timing of failure for planted softwood stock to regenerate, and the options to adapt by either planting genetically modified softwood stock, or planting hardwood stock on harvested softwood plantation areas.

Each climate change and adaptation scenario is fed into a Woodstock forest management model (Remsoft 1997) to produce softwood and hardwood timber production estimates from 2020-2095. The timber production estimates are then scaled-up to the provincial level, converted into softwood and hardwood stumpage values, and used as inputs into a single region, recursive dynamic CGE model, calibrated to the New Brunswick economy.

For each scenario, we present the dynamic impacts on a series of forest-level indicators (e.g., tree species volume harvested, aggregated softwood and hardwood volume harvested) and economic indicators (e.g., sector output values; prices; household consumption; government expenditures; export and import values; labour, capital, and stumpage value expenditures; GDP). We also conduct a preliminary cost-benefit analysis of selected adaptation options associated with modified planting regimes. 
This research is important as it builds on previous studies investigating the biophysical and economic impacts of climate change in forests. To our knowledge, this is the first study to assess the economics of climate change by coupling a forest management model with a CGE model. Previous analysis has either used ecological models or relied on literature in other regions to infer timber supply impacts and use them in CGE models. Furthermore, while previous CGE model analyses have focused on examining the effects of aggregated timber supply changes on the economy, our analysis will better account for individual softwood vs. hardwood timber supply changes by disaggregating the logging sector into softwood and hardwood sub-sectors. These methodological advances will help create more accurate economic impact estimates, and also provide the basis to better inform future forest management plans that aim to adapt to the damage caused by climate change.

The remainder of this article is organized as follows. Section 2 describes the methods used to model the timber supply and economic impacts of climate change and adaptation. Section 3 provides the results of the analysis. Finally, Section 4 presents a discussion of the findings, outlines some of the limitations, and concludes the study.

[1] Other economic analysis of climate change impacts on Canadian and/or North American forests include Nordhaus (1991), Mendelsohn et al. (2000), Kemfert (2002), Hope (2006) and a host of others who use integrated assessment and CGE models of the world economies. However, since these studies incorporate the effects of climate change on many sectors at once (e.g., forest, agriculture, energy, human health, etc.), and as such the contribution of forestrelated impacts is not identified.

\section{Methods}

Forest management modeling:

To assess the impacts of climate change on New Brunswick's forests, we update and extend a New Brunswick Department of Natural Resources and Energy Development (NB DNRED) Crown land forest management model, which uses Remsoft Inc.'s Woodstock forest management software.[2] Within the software, forest features such as initial stand types, age class distributions, areas, stand yields, natural transition patterns, disturbance transition patterns, and possible forest interventions (e.g., clearcutting, partial-cutting, commercial thinning, planting and pre-commercial thinning) are represented for each Crown license. In our analysis, an 80-year planning horizon is defined and time periods are specified by 5-year intervals, beginning in 2020 . Additionally, over $1000+$ stand types and 40 species composition types are defined in the model. The model tracks volume harvested by all of these species separately.

Once an objective function and constraints are defined in the model, the model files are served into the linear programming optimization software MOSEK (2004). Woodstock takes the solution provided by MOSEK and calculates the results (e.g., area treated, volume harvested) over time in user-defined report files. In our analysis, we employ a typical objective function of maximizing total volume of merchantable timber harvested over the 75-year planning horizon with a $5 \%$ discount rate to value harvest today higher than harvest later in the planning horizon. Harvesting constraints include non-declining harvest constraint under baseline (no climate change) conditions, upper bounds on silviculture amounts tied to provincial silviculture budget constraints, non-declining operable growing stock after 2080, and period-to-period flow-control on area treated by treatment. Forest indicators of particular interest for the current analysis include softwood and hardwood harvest levels ( $\mathrm{m}^{3}$ per period).

Wood volume is measured in the model through stand-type volume yield curves. Yield curves were originally developed by the NB DNRED Growth and Yield Unit using the Open Stand Model - Acadian Variant (www.forusresearch.com) to produce 5-year period forecasts of merchantable volume of wood by each stand type and species product group. Forest succession dynamics in the model are based on New Brunswick historical regeneration observations from 1990s-2000s (pre-cut) timber surveys and photo-interpreted post-cut succession response (proportion of species composition types; i.e., FUNA types).

To account for future climate change effects on forest succession, a GBM (gradient boosted machine ensemble classification trees) model was used to predict the multinomial distribution of regenerating FUNA types as a function of: (i) climate variables (mean annual temp, DJF mean temp); (ii) disturbance type (clearcut, overstory removal); and (iii) pre-cut FUNA type (from timber cruise).

It should be noted here that, under the IPCC's climate change condition RCP 8.5 temperature (even in the highlands) will exceed that of southern New Brunswick by 2080, so the GMB model is very limited by New Brunswick's geographic climate range and cannot be confidently used for southern New Brunswick beyond 2035 and northern New Brunswick beyond 2050. Therefore, we consulted Natural Resource Canada's tree species climate-suitability maps (planthardiness.gc.ca; MaxEnt; composite-AR5; RCP8.5) for periods 2040-2070 and 2070-2010 for all commercial tree species in New Brunswick to roughly estimate relative reductions in suitability from today to 2100 for: (i) southern ecoregions 5, 6 and 7; northern ecoregions 2 and 3; and (iii) highlands/Fundy coast ecoregions 1 and 4, where suitability was assumed to relate to probability of successful natural regeneration.

Where species were not expected to successfully regenerate/compete using the climate-suitability maps, a zero multiplier was used in the yield curve indicating these species would no longer regenerate naturally. By setting these unsuitable FUNA to zero, remaining proportions of suitable FUNA were proportionally increased to sum to $100 \%$. Remaining FUNA will still contain trace to low amounts of other non-suitable species, but the dominant species regenerating will largely shift toward more suitable species in the succession matrix.

\section{Economic modeling:}

CGE models are a class of economic impact models that use economic data to estimate how an economy might react to changes in policies, markets, technologies or other such factors. CGE modeling has become a popular tool for analyzing economic and welfare impacts of policy options in natural resources management. Researchers have applied this technique to examine a wide range of forest-related policies and natural/human disturbances such as land-use changes (Zhang et al. 2005), pest outbreaks (Liu et al. 2019; Corbett et al. 2016; Chang et al. 2012), environmental regulations (Das et al. 2005), deforestation (Banerjee and Alavalapati 2009), and climate change (as previously described).

Page 3/16 
We develop a single-region, recursive dynamic CGE model for the New Brunswick economy. The model is based on the neoclassical modeling tradition originally developed by Dervis et al. (1982). The basic specification is similar to that used in some of our previous work (e.g., Liu et al. 2019; Corbett et al. 2016) but is augmented in two ways: (i) we break out several forest manufacturing sectors from the aggregated manufacturing sector (as a result of Statistics Canada now providing this level of detail); and (ii) we break out softwood and hardwood logging sectors from the aggregated logging sector. This latter augmentation was required to match-up with the different effects that climate change will have on softwood vs hardwood tree species.

The model is formulated as a set of simultaneous linear and non-linear equations, consisting of a household block, a government block, a trade block, and a production block (see the Appendix in supplemental materials for the model equations). The first three blocks are as described in Liu et al. (2019).

In the production block, New Brunswick is assumed to be a small open economy consisting of 27 sectors (see Table 1), 8 of which represent the forest sector directly (i.e., S-FOR, H-FOR, SAW-MANUF, VEN-MANUF, OW-MANUF, PULP-MANUF, CP-MANUF, and PR-MANUF). Each sector is modeled as a representative firm, who uses intermediate inputs supplied from other sectors and value-added production based on factors of production to produce a sector specific commodity. This production, along with imports, represents supply of commodities. The factors of production include labour, capital, and stumpage value (the latter of which is only used in the softwood and hardwood logging sectors). Labour and capital are assumed to be mobile across sectors. In each sector, demand for this commodity comes from other firms (other sectors) that use it as an intermediate input, and final demand which includes consumption, government consumption, investment and exports. Supply equals demand for all commodities in all sectors.

A nested constant elasticity of substitution CES structure is used to model the production process outlined above, as this allows for a trade-off between inputs at different levels (or nests). At the top nest, a composite (or bundle) of labour, capital and stumpage value is combined with intermediate inputs using a fixedshare Leontief technology.[3] At the second level, producers who use stumpage (i.e., the hardwood and softwood forestry \& logging sectors) choose between a labour-capital bundle and either a hardwood or a softwood stumpage value (these stumpage inputs are sector-specific). At the third level, producers choose between labour and capital. In nests two and three, the choice of inputs are made by minimizing the costs of production subject to a CES production function. The price of final output in each sector is derived from the combined costs of value-added and intermediates.

The model is calibrated by constructing a social accounting (SAM) matrix for the New Brunswick economy in 2015, using Statistics Canada's symmetric input-output tables (Statistics Canada 2015a). The "detail level" data are used, which breaks the provincial economy into more than 200 sectors. We aggregate this data into the 27 sectors shown in Table 1. Liu et al. (2019) provide details on constructing and balancing the SAM.

While the New Brunswick 2015 input-output table provides most of the required data to complete the SAM, it does not specifically include hardwood and softwood stumpage values. Rather, stumpage payments in the forestry and logging sectors are embedded in each sector's 'other operating surplus' as a component of capital. To isolate stumpage values as inputs, we build on Ochuodho and Lantz (2014) by using total revenue estimates from the sale of stumpage on provincial Crownland (CCFM 2020) as the starting point for calculating total stumpage revenues. We then determine the components of total revenue by using the volume of harvested merchantable wood by species and grade (logs and bolts, pulpwood and fuel and firewood) on Crownland with the corresponding prices (NBFPC 2016) in 2015. We then scale-up the Crown land stumpage revenue estimates to the provincial level by adding private land stumpage revenues, based on the volume of merchantable wood by species and grade harvested on private land and corresponding prices in 2015 (NRCan 2020).[4]

New Brunswick's 2015 input-output table also does not distinguish between the hardwood forestry \& logging sector and the softwood forestry \& logging sector. Instead, both are aggregated within the forestry \& logging sector. To disaggregate the forestry \& logging sector we use New Brunswick's 2015 supply and use table (Statistics Canada, 2018) in conjunction with the total dollar value of timber by grade per species. The supply and use table shows the dollar value of timber by grade used as intermediate goods across sectors in New Brunswick. To determine the dollar value of timber by grade per species we multiply the total harvested merchantable volume of timber by grade per species in 2015 (CCFM 2020) with corresponding prices (NBFPC 2016). This allows us to determine the proportion of which hardwood and softwood contribute to the value of timber by grade. We then use this proportion to disaggregate the intermediate demand for timber by grade into intermediate demand for hardwood and softwood timber by grade. This is followed by summing the speciesspecific value of timber used as intermediate goods across individual sectors, which allow us to determine the fixed share in which sectors demand hardwood to softwood intermediate goods. This fixed share is then applied to the intermediate demand in New Brunswick's 2015 SAM.

The above adjustments create an imbalance within the SAM. To rebalance the SAM, we create a linear solver[5] that redistributes the imbalance as a fixed proportion to the interactions occurring between the individual forestry \& logging sectors and all non-forestry related sectors and entities. This process not only allows us to re-balance the SAM but also create a SAM that has unique inputs and outputs for the both the hardwood and softwood forestry \& logging sectors.

In addition to the baseline data outlined above, several other parameters are estimated to accurately reflect the economy of New Brunswick in the base year. Elasticity parameters, including income elasticity, elasticity of substitution, and elasticity of transformation, are derived from the GTAP database (GTAP 2018) and Corbett et al. (2016)[6].

We use the General Algebraic Modeling System software with a nonlinear programming algorithm and the CONOPT3 solver (GAMS 2018), to implement the model. The model is initially solved in static form to replicate 2015 data. Checks are conducted to ensure that the model solves without infeasibilities with zero iterations, that the model is square, that Walras law is satisfied, that the model is homogenous of degree zero, and that base year data is replicated.

Following the static general equilibrium solution, the model is solved recursively over a 90-year (2015-2105) time frame. Recursive dynamics is incorporated in the model through growth in capital supply, labour supply, and stumpage value. A capital accumulation equation, which uses an endogenous return rate on capital and total savings (Ochuodho and Lantz 2014), is used to model capital supply growth. Labour supply growth is exogenous and assumed to grow by

Page $4 / 16$ 
$0.1 \%$ annually in the model, based on labour supply growth projections from Statistics Canada (Statistics Canada 2020). [7] Stumpage value growth will depend on the various scenarios considered in our analysis (discussed below).

As factor inputs change over time, the direct changes in productive capacity and income will cause the economy to expand or contract. This will have secondary effects on final and intermediate demand, leading to changes in other macroeconomic variables. In our analysis, we focus on changes to key macroeconomic variables such as income, consumption, GDP, equivalent variation[8], exports, imports, and production by sector. Values are presented annually and in present value, real terms (\$2015) using a $2 \%$ real discount rate (reflecting the historical rate of return of long-term government bonds).

\section{Coupling the models:}

Once calibrated with a set of climate, forest, and management parameters (scenarios are described below), the Woodstock model is run over the 20202100 period, and produces estimates of hardwood and softwood harvest volumes (in terms of $\mathrm{m}^{3}$ ) on New Brunswick's Crown land, which represents approximately $50 \%$ of forestland in the Province. Since our intention is to assess the impacts of climate change on the entire Province's forests, we need to scale-up the harvest estimates. We initially investigated extending a private land Woodstock model currently under development by NB DNRED, however, we felt the uncertainties in management actions (rates of harvest, silviculture investment) for private woodlots would limit our confidence in the model output. Instead, we make a simplifying assumption that our estimated timber production changes over time on Crown land in New Brunswick are representative of the entire forest land base of the province. That is, when our model predicts that Crown land timber supply changes by a certain percentage, we assume private land timber supply changes by the same percentage, resulting in an equivalent percentage change in total timber supply in the province. While there exist some differences in forest area, forest types and management regimes between ownership types that need to be accounted-for in the future (see Table 2 for a comparison), the assumption made here allows us to proceed with our model coupling analysis.

To couple the models, we take the percentage change estimates in softwood and hardwood harvest volumes over time produced from the Woodstock model and use them to adjust the hardwood and softwood stumpage value inputs in the CGE model over the same period of time.

\section{Scenarios:}

We consider 4 scenarios in our analysis.[9] Scenario 1 is the Baseline, where labour supply grows at $0.1 \%$ annually, climate change does not occur, planting continues at current rates, and all plantations are assumed to survive. The next three scenarios include different assumptions about climate change, its effects on forest succession/plantations, and options to adapt. In each of these scenarios, we consider only the most extreme IPCC climate change condition, namely RCP 8.5. We focus on RCP 8.5 in this report because other commonly used IPCC conditions, namely RCP 2.5 and 4.5 , were not expected to result in significant impacts on timber supplies over time. For instance, under RCP 4.5, red spruce is still considered suitable by $2070-2100$ (see planthardiness.gc.ca; MaxEnt; composite-AR5; RCP4.5), so the Woodstock model would simply shift from planting such species as white spruce to red spruce. As such, these other IPCC climate change conditions were not analysed.

Scenario 2 considers the effects of climate change RCP $8.5 \mathrm{in:}$ (i) altering forest succession such that a number of species (mostly softwoods) will not be successful in naturally regenerating/competing; and (ii) increasing drought conditions such that all spruce plantations established in 2020+ fail before they can be harvested in 2055+. In our scenario, we assume this failure is due to increased extreme drought conditions.[10]

Scenario 3 considers the same climate change conditions as Scenario 2, however climate-resistant seedlings are used to successfully maintain all plantations established in 2020+. This adaptation option is being given serious consideration in the recent NSERC funded Silvi21 national project, of which one project involves translocation of current seed sources to the south-east US to identify likelihood of current seedling survival under much warmer conditions and also to select for drought resistant genotypes for future spruce plantations (L. D’Orangeville, UNB, personal communication, 2021).

Scenario 4 considers the same climate change conditions as Scenario 2, however in this case, climate resistant commercial hardwood species (e.g., red maple, sugar maple, oak) are planted on areas previously planted to spruce as well as other non-commercial/poorly-regenerating areas as they become available. Red maple seedlings in particular have shown to be quite resilient in the face of drought conditions (Vaughan 2021). Hardwood plantations are currently being considered in New Brunswick by the New Brunswick Department of Energy and Resource Development to help achieve both Acadian forest restoration and climate change mitigation goals (C. Hennigar, NB ERD, personal communication, 2021). A key hurdle in widespread implementation of hardwood plantations is expected to be cost, as seedlings need to be much larger and fenced to prevent browse. Another major hurdle is existing manufacturing capacity and dependence on strong softwood lumber markets across the province; equivalent markets for increases in HW saw and pulp material in the future are not clear.

\section{Economic impact and cost-benefit analysis:}

To assess the economic impacts of climate change without and with adaptation, we present a comparison of the economic variable outcomes produced by the CGE model under Scenarios 2, 3 and 4 with those of Scenario 1 (the Baseline). We present these comparisons in both time-trend figures and tables, the latter of which includes current and present values (using a $2 \%$ discount rate, reflecting the average historical real return on risk-free Canadian government bonds).

We also present a preliminary cost-benefit analysis of the two adaptation options considered in this analysis (i.e., Scenarios 3 and 4 ), where the cost is equivalent to the present value financial expenditures needed to implement the adaptation activity, and the benefit is equivalent to the increase in present value welfare (i.e., equivalent variation) over time moving from the climate change Scenario 2 to adaptation Scenario 3 or 4 . We present our analysis in terms of cost-benefit ratios and net present values (both using a $2 \%$ discount rate, representing the historical average real interest rate of government bonds), with adaptation being supported in cases where the former measure is equal to or greater than 1 , and the latter measure is equal to or greater than 0 . The costbenefit ratio measures the cost effectiveness of the investment, while the net present value measures the overall efficiency of the investment. 
Costs associated with implementing Scenario 3 (Plant Drought-Resistant Seedlings) are based on a core assumption that the tree improvement workload in New Brunswick would have to double in order to continue the current pace of volume gain improvements while introducing improvement in drought tolerance. The cost increases would be mostly variable but some fixed costs would be associated with infrastructure. Workload increases would include grafting, breeding, field trial establishment and management, data collection, and analysis. A single round of R\&D would be required to understand the fundamentals of drought tolerance breeding with Acadian conifer species over the first five years. Specific costs are estimated as follows: (i) additional office, lab, greenhouse space for growing field trials at $\$ 500 \mathrm{k}$ in first year; (ii) R\&D activities to develop drought tolerance breeding strategy at $\$ 400 \mathrm{k}$ spread over first 5 years; (iii) salaries, benefits, vehicles, and related costs for additional tree improvement professionals and technicians at $\$ 555 \mathrm{k} / \mathrm{yr}$; (iv) maintenance and up-keep for the additional office, lab, and related infrastructure at $\$ 20 \mathrm{k} / \mathrm{yr}$; (v) additional materials and supplies including herbicide, field tags, data recorders, greenhouse supplies for growing field test seedlings, etc. at $\$ 45 \mathrm{k} / \mathrm{yr}$; and (vi) additional contract work for incremental test sites, including mechanical site prep, weed control, etc. at \$15k/yr (Josh Sherrill, Leader of Forest Productivity, JD Irving Ltd, personal communication, 2021).

Costs associated with implementing Scenario 4 (Plant Hardwood) are based on the core assumption that a planting program would require additional silviculture investments to successfully establish hardwood stands. R\&D efforts would be required early on to better understand seed procurement and stratification, nursery growing, planting practices, weed control requirements, stand tending, and growth and yield to create silviculture best management practices and achieve desired commercial product outcomes. Specific costs are estimated as follows: (i) R\&D activities to develop hardwood silviculture program, including program leader, research staff, field studies, data analysis, and reporting at $\$ 800 \mathrm{k}$, spread over first 5 years; (ii) incremental seedling costs at \$12.52 mill/yr[11]; (iii) incremental planting costs at \$2.5 mill/yr[12]; and (iv) incremental silviculture costs at \$10 mill/yr[13] (Josh Sherrill, Leader of Forest Productivity, JD Irving Ltd, personal communication, 2021).

[2] Woodstock is used worldwide for strategic forest planning and management (Walters 1993). Recent academic studies that use of the software in the context of climate change and adaptation include: Dymond et al. (2020), Lundholm (2020; 2019), and Dhital et al. (2015).

[3] Fixed-shares are used for intermediates since their proportions are mostly determined by existing technology rather than producer decision-making. [4] This method is based on the assumption that private land stumpage rates are the same as those on Crownland, which is the policy of the Provincial government (NBFPC 2016).

[5] The linear solver was created in Excel using a modified RAS approach (McDougall 2000) to rebalance both the hardwood forestry \& logging sector and the softwood forestry \& logging sector. Cells within these sectors that were disaggregated using New Brunswick's 2015 supply and use table (Statistics Canada 2015b) were considered constant, while the remaining cells were multiplied by a fixed proportion (specific to each forestry sector) to ensure that the sum of the sector's row equals the sum of the sector's column. We added an additional equation to the solver to ensure that the sum of both the hardwood forestry \& logging sector and the softwood forestry \& logging sector had to be equal to that of the original forestry and logging sector found in New Brunswick's 2015 input out table (Statistics Canada 2015a).

[6] Following Corbett et al. (2016), we assumed relatively low substitution elasticities between stumpage and capital/labour since published data is not available for these parameters. This is a typical assumption in forest-related CGE studies on grounds that stumpage is largely a required factor in the production of forestry \& logging sector output.

[7] For sensitivity analysis purposes, we also consider a growth scenario in labour supply of $0.5 \%$ annually. However, this did not affect the general findings in this study. Results are available from the authors upon request.

[8] Equivalent variation is the change in wealth, at current prices, that would have the same effect on consumer welfare as would the change in prices, with income unchanged. It is measured as the difference between: (i) the supernumerary income that would exist under the proposed change divided by a price index that reflects the change in prices under the proposed change; and (ii) the supernumerary income that exists under baseline conditions.

[9] As noted above, Appendix I provides a parallel set of scenarios assuming a higher labour supply growth rate.

[10] The plantation failure could be due to a number of factors including drought, pest, disease, or other such factors. This is an extreme scenario as we do not know the mechanism of species climate unsuitability. If suitability is limited only moderately by seedling survival, then plantations established in $2020-2040$ (before suitability substantially declines) may continue to grow well until time of harvest in 2060-2080. In this case, there would be very little impact on harvest. It is really only under the extreme scenario that assumes plantations established in 2020 and beyond will fail, that we see significant harvest impacts.

[11] Calculated as the difference between the cost of growing hardwood vs conifer seedlings. Here, we assume conifer seedling growing costs are $\$ 0.18 /$ tree, conifer planting density is 1,800 trees per ha, hardwood seedling growing costs are $\$ 0.38 /$ tree, and hardwood planting density is 2,500 trees per ha (to account for anticipated survival issues). Since there is currently 10,000 ha of forest planted on Crownland annually, and Crownland is approximately $50 \%$ of all forested area in the province, we assumed that 20,000 ha of forestland would be planted annually as hardwood plantations over the $2021-2095$ period. [12] Calculated as the difference between the cost of planting hardwood vs conifer seedlings. Here, since hardwood seedlings are larger, we assume it would cost an additional $\$ 0.05 /$ tree to plant. This was multiplied by a hardwood planting density of 2,500 trees/ha, and then by 20,000 ha of forestland planted annually as hardwood plantations over the 2021-95 period.

[13] Calculated as two additional weed control treatments at $\$ 250 /$ ha for each treatment, and multiplied by 20,000 ha of treated forestland annually.

\section{Results}

\section{Wood supply impacts:}

Figures 1 and 2 provide the respective hardwood and softwood timber supply estimates produced by the Woodstock model from 2015 to 2095 under the different scenarios considered. The trend in Hardwood timber supply is similar and constant over time under all scenarios except under Scenario 4 (Plant Hardwood), where it increases up to $26 \%$ by 2095 relative to the Baseline, as hardwood plantations start to mature. 
Softwood timber supply, on the other hand, is reduced below the Baseline under all other scenarios. The largest decrease is observed under Scenario 2 (Climate Change) where softwood timber supply is reduced by up to $26 \%$ below the Baseline by 2095 . The reduction of softwood timber supply is surprisingly less significant under Scenario 3 (Plant Hardwood), where it is only reduced by up to $10 \%$ below the Baseline by 2095 (one would have expected similar reductions under Scenarios 2 and 3). Further investigation into the cause of this in the Woodstock model reveals that there is a significant amount of spruce-fir ingrowth under Red Maple and Tolerant hardwood plantation yields.[14] Finally, the softwood timber supply reduction is much less under Scenario 4 (Plant Drought-Resistant Seedlings) compared to Scenario 2 (Climate Change), where it is reduced by only up to $5 \%$ below the Baseline by 2095 . This reduction emerges from the climate-induced change in successional dynamics which cause more hardwood and pine, compared to spruce and fir, to be naturally regenerated following harvest.

\section{Economic impacts:}

Figures 3 and 4 provide hardwood and softwood stumpage price estimates produced by the CGE model from 2015 to 2095 under the different scenarios considered. These generally follow the inverse of the respective timber supply trends, where for instance hardwood prices decline under scenarios that exhibit hardwood timber supplies increase, and vice-versa for softwood. This is a result of factor market demand and supply conditions - when timber supply becomes more scarce, its price increases, and vice-versa. Overall, Scenario 4 (Plant Hardwood) exhibits the largest hardwood stumpage price decrease at $75 \%$ relative to the Baseline by 2095. Scenario 2 (Climate Change) exhibits the largest softwood price increase at 3.5 times the Baseline by 2095 .

Tables 3 and 4 provide the sector-level output quantity and price estimates by scenario in 2095, respectively. In Table 3, softwood forestry \& logging sector output quantity is reduced by $12 \%$ under Scenario 2 (Climate Change) relative to the baseline. Additionally, the output quantity of most forestry related manufacturing sectors exhibiting significant declines ranging from $7 \%$ to $27 \%$ (except paper manufacturing). This follows from the $26 \%$ decrease in softwood timber supply in this scenario (see Figure 2). Output quantity in the Hardwood forestry \& logging sector and the Pulp manufacturing sector is increased by approximately $2 \%$ under Scenario 4 (Plant Hardwood) relative to the Baseline by 2095 . This follows from the $26 \%$ increase in hardwood timber supply in this scenario (see Figure 1).

In Table 4, sector output prices generally follow the inverse of the respective output quantities. This, again, is a result of market demand and supply conditions - when output becomes scarce, its price increases, and vice-versa. The Softwood forestry \& logging sector output price increases by as much as $5 \%$ under Scenario 2 (Climate Change), while Hardwood forestry \& logging sector output price decreases by as much as $2.5 \%$ under Scenario 4 (Plant Hardwood) by 2095.

There are a several sectors (e.g., CROP, FISH, OILGAS, OTH-MANUF, TRANP) that experience an increase in output $(0.01 \%$ to $4.02 \%$ ) under all three scenarios, with the largest increases occurring under Scenario 2 (Table 4). These sectors can be divided into two groups, the first of which (CROP, FISH, OILGAS) are sectors that heavily rely on capital as a factor of production and are able to take advantage of the economy-wide depreciation of capital to increase their output. The second group (OTH-MANUF, and TRANP) are sectors that are strongly connected to the first group though their demand of intermediate goods and services. This connectivity between sectors creates a trickle-down effect that causes the second group of sectors to experience an increase in output due to the increase in output from the first group.

Table 5 presents several macro-economic variables by scenario in 2095. Here, GDP exhibits the largest decrease at approximately $0.33 \%$ under Scenario 2 (Climate Change), relative to the Baseline. Scenarios 3 and 4, on the other hand, exhibit much smaller GDP changes relative to the Baseline. The relatively small GDP changes result from the offsetting changes in GDP components. Specifically, while consumption and government expenditures tend to decline, investment and exports tend to increase. Imports and exports are the only two GDP components that experience increases under all scenarios, with the largest increase occurring in Scenario 2 at approximately 1.3 to $1.4 \%$. The increase in imports was driven by the increase in price of domestic output, while the increase in exports were driven by both the increase in imports as well as foreign saving being fixed (market closure) within our model. With foreign savings being fixed, exports increased in order to ensure that the market clearing condition for the Rest of the World was met.

Regarding other macroeconomic variables in Table 5, equivalent variation, labour, capital, and output produced and consumed domestically tend to be most negative under Scenario 2 (Climate Change) and least negative under Scenario 4 (Plant Hardwood).

Table 6 presents cumulative present value macro-economic variables by scenario over the $2015-2095$ period. While the signs of each variable are generally the same as in Table 5, the percentage differences are much smaller since variable changes that are far off in the future are heavily discounted. Here it is observed that the largest variable declines are again under Scenario 2 (Climate Change) relative to the Baseline.

\section{Cost-benefit analysis:}

Tables 7 and 8 present the cost-benefit analysis of: (i) planting drought resistant softwood seedlings; and (ii) planting hardwoods in place of failed spruce plantations, respectively. For the former adaptation option, the benefit-cost ratio is greater than one and the net present value is greater than 0 , indicating that planting drought resistant softwood seedlings would be both cost effective and efficient. The opposite is true for the latter adaptation option, indicating that planting hardwoods in place of failed softwood plantations is neither cost effective or efficient. Therefore, this analysis supports the former over the latter adaptation option.

[14] This undergrowth may be unlikely under RCP8.5. Our base yield (historic species composition and growth) for red maple was not modified to account for this. In future analysis, we may consider this in the model by simulating a near pure HW plantation stand type for these areas.

\section{Discussion}


In this study, we couple a forest management model with a CGE model to analyze the potential climate change impacts and adaptation on New Brunswick's timber supply and economy. We focus our analysis on the effect that climate change will have on forest succession and the potential failure of spruce plantations. While we find that these climate change effects will have relatively large negative impacts on softwood timber supply (up to a $26 \%$ reduction by 2095), softwood forestry \& logging sector output quantity (up to a $12 \%$ reduction by 2095 ), and forestry related sector output (ranging from $6 \%$ to $27 \%$ reduction by 2095), they will have relatively small impacts on GDP (up to a $0.33 \%$ reduction by 2095) and the macroeconomic variables that make it up such as consumption, income, and government expenditures. The relatively small impact on the provincial GDP was due to both forest related outputs making up a relatively small share of overall output in New Brunswick as well as several sectors (CROP, FISH, OILGAS, OTH-MANUF, and TRANSP) experiencing an increase in output under all climate change scenarios.

It is important to note here that, although the model shows several sectors increasing output under climate change scenarios, factors outside of our analysis may limit this from happening. For instance, the sectors that experienced the largest increase in output tend to be those that require natural capital (farm land, fish and game stocks, and natural gas, oil and mineral reserves) which may themselves be limited by climate change (Allison et al., 2009; Fezzi \& Bateman, 2015; Mu et al., 2013) and climate policy (Bauer et al., 2016). In our study the only natural capital that was distinguished from regular capital was hardwood and softwood stumpage. The remaining payments for natural capital (land rent, fishing and hunting licenses, and oil, gas, and mineral royalties) were left within general capital rent payments. As such the economic impact of climate change altering New Brunswick's timber supply may be greater than what is reported in our analysis as those sectors depending on natural capital may themselves be negatively impacted.

Adapting to climate-related changes in timber supply by planting drought-resistant softwood seedlings or hardwood seedlings in place of failed softwood plantations can minimize the negative impacts, and in the latter case, positively impact hardwood timber supply and associated sector output quantity. While the former adaptation option is supported on economic grounds using cost-benefit analysis, the latter is not. The major reasons that planting hardwoods in place of failed softwood plantations is not supported on economic grounds has to do with the large incremental costs of growing, planting, and treating/tending the relatively larger hardwood seedlings to ensure successful growth. If hardwood product values and value-added processing were to increase substantially over time, it could help this adaptation option become more economically viable.

There are a number of caveats that need to be considered when interpreting or relying on the estimates/conclusions in this study. First, we made numerous simplifying assumptions regarding the scaling-up of our Woodstock timber supply modeling of Crownland to all of New Brunswick's forests (which includes Crown and private land). Future analysis needs to include the modeling of private forest land. We also do not consider the potential climate-induced changes in pest, fire, and disease regimes in our analysis. These are widely expected to cause additional negative impacts on forests and timber supplies in the region (Taylor et al. 2017) and should be considered in future analysis.

There are additional caveats when interpreting the results that emanate from our CGE modeling. First, we assume that domestic prices will respond to domestic demand and supply conditions according to calibrated national price elasticities. However, it may be that these elasticity estimates do not apply to a relatively small region such as New Brunswick, where domestic demand and supply conditions (particularly for forest products) don't affect domestic prices to the same extent as they would for larger market economies. Additionally, we don't have data on input factor substitution elasticities in the forestry and logging sectors. Here, we simply assume these to be relatively low. Different price and input substitution elasticity estimates have the potential to significantly affect the economic impact estimates produced in this study. Therefore, additional primary research into calibrating these elasticity estimates is needed in future studies.

One must also be careful when interpreting our adaptation cost-benefit analyses, as these are based on very preliminary costing estimates provided by industry experts. A more thorough budgeting of the costs associated with developing a drought resistant seedling program and growing/planting hardwood species is needed. Additionally, we do not factor in the risk associated with the success/failure of either of these adaptation programs.

Overall, while our findings should be treated with caution, they provide the first estimates of climate change effects on the forest and the economy using a coupled Woodstock and CGE modeling framework. Future studies can expand this analysis to other regions and climate factors, using single-region and multiregion CGE models, to help guide decision-making around forest management in the face of a changing climate.

\section{Declarations}

Acknowledgements: Funding for this project was provided by Natural Resource Canada's Climate Change Adaptation Program. The authors would like to thank the New Brunswick Department of Natural Resources \& Energy Development, and the Northern Hardwood Research Institute for their collaboration in this project. We would also like to thank Josh Sherrill, Leader of Forest Productivity at JD Irving Ltd, for providing cost estimates associated with various planting programs considered in our analysis.

\section{Compliance with Ethical Standards:}

- Disclosure of potential conflicts of interest: The authors declare there are no financial nor non-financial conflicts of interest in the production or dissemination of this research.

- Research involving human participants and/or animals; and informed consent: The authors declare that there were no human participants or animals involved as subjects in this research. As such, informed consent to participate as subjects was not necessary.

- Consent to Publish: All authors consent to publish this research as presented.

- Authors Contributions: All authors contributed to the study conception and design. The Woodstock model was developed and simulated by Chris Hennigar and colleagues at NB DNRED. The CGE model was developed by Van Lantz, Galen McMonagle, Chinmay Sharma, Patrick Withey, and Thomas 
Ochuodho. CGE simulations and data analysis were performed primarily by Galen McMonagle. The first draft of the manuscript was written by Van Lantz and all authors commented on previous versions of the manuscript. All authors read and approved the final manuscript.

Data Availability: The datasets generated during and/or analysed during the current study are available from the corresponding author on reasonable request.

\section{References}

Allison, E. H., Perry, A. L., Badjeck, M. C., Neil Adger, W., Brown, K., Conway, D., Halls, A. S., Pilling, G. M., Reynolds, J. D., Andrew, N. L., \& Dulvy, N. K. (2009). Vulnerability of national economies to the impacts of climate change on fisheries. Fish and Fisheries, 10(2), 173-196.

Bauer, N., Mouratiadou, I., Luderer, G., Baumstark, L., Brecha, R. J., Edenhofer, O., \& Kriegler, E. (2016). Global fossil energy markets and climate change mitigation - an analysis with REMIND. Climatic Change, 136(1), 69-82.

Banerjee O, Alavalapati J (2009). A computable general equilibrium analysis of forest concessions in Brazil. Forest Policy and Economics 11(4): $244-252$.

Boccanfuso D, Savard L, Goyette J, Gosellin V, Mangoua C (2018). An impact analysis of climate change on the forestry industry in Quebec. Canadian Journal of Forest Research 48: 216-226.

Chang Y, Lantz V, Hennigar C, MacLean D (2012). Economic impacts of forest pests: a case study of spruce budworm outbreaks and control in New Brunswick, Canada. Canadian Journal of Forest Research 42: 490-505.

CCFM (2020). National Forestry Database. Canadian Council of Forest Ministers. Available at: http://nfdp.ccfm.org/en/index.php (accessed March 2, 2021).

Corbett LJ, Withey P, Lantz VA, Ochuodho TO (2016). The economic impact of the mountain pine beetle infestation in British Columbia: provincial estimates from a CGE analysis. Forestry 89: 100-105.

Das GG, Alavalapati JRR, Carter DR, Tsigas ME (2005). Regional impacts of environmental regulations and technical change in the US forestry sector: a multiregional CGE analysis. Forest Policy and Economics 7: 25- 38.

Dervis K, de Melo J, Robinson S (1982). General Equilibrium Models for Development Policy. Cambridge University Press, New York.

Dhital N, Raulier F, Bernier PY, Lapointe-Garant M, Berninger F, Bergeron Y (2015). Adaptation potential of ecosystem-based management to climate change in the eastern Canadian boreal forest. Journal of Environmental Planning and Management 58(12): 2228-2249.

D’Orangeville L, Côté B, Houle D, Morin H (2013). The effects of throughfall exclusion on xylogenesis of balsam fir. Tree Physiology 33:516-526.

Dymond C, Giles-Hansen K, Asante P (2020). The forest mitigation-adaptation nexus: economic benefits of novel planting regimes. Forest Policy and Economics 113: 102124.

Fezzi, C., \& Bateman, I. (2015). The impact of climate change on agriculture: Nonlinear effects and aggregation bias in ricardian models of farmland values. Journal of the Association of Environmental and Resource Economists, 2(1), 57-92. https://doi.org/10.1086/680257

Fisichelli N, Wright A, Rice K, Mau A, Buschena C, Reich PB (2014). First-year seedlings and climate change: species-specific responses of 15 North American tree species. Oikos 123:1331-1340.

GAMS (2018). General Algebraic Modeling System. GAMS Development Corporation, Washington, DC. Available at: https://www.gams.com/ (accessed: April 1, 2018).

GTAP (2018). Global Trade Analysis Project (GTAP) Database. Available at: https://www.gtap.agecon.purdue.edu/default.asp (accessed: April 15, 2018).

Hope C (2006). The marginal impact of $\mathrm{CO}_{2}$ from PAGE2002: An integrated assessment model incorporating the IPCC's five reasons for concern. Integrated Assessment 6(1): 19-56.

Kemfert C (2002). An integrated assessment model of energy-economy-climate - the model Wiagem. Integrated Assessment 3(4): 281-298.

Lemprière TC, Bernier PY, Carroll AL, Flannigan MD, Gilsenan RP, McKenney DW, Hogg EH, Pedlar JH, Blain D. (2008). The importance of forest sector adaptation to climate change. Natural Resources Canada, Canadian Forest Service, Northern Forest Centre, Edmonton, Alberta. Information Report NOR-X-416.

Liu E, Lantz V, MacLean D, Hennigar C (2019). Economics of early intervention to suppress a potential spruce budworm outbreak on Crown land in New Brunswick, Canada. Forests 10(6): 481-505.

Lundholm A, Black K, Corrigan E, Nieuwenhuis M (2020). Evaluating the impact of future global climate change and bioeconomy scenarios on ecosystem services using a strategic forest management decision support system. Front. Ecol. Evol. 8: 200; doi:10.3390/10.3389/fevo.2020.00200

Lundholm A, Corrigan E, Nieuwenhuis M (2019). Implementing climate change and associated future timber price trends in a decision support system designed for Irish forest management and applied to Ireland's western peatland forests. Forests 10: 270; doi:10.3390/f10030270 
McDougall, R. A. (2000). Entropy Theory and RAS are Friends. Available at: https://www.gtap.agecon.purdue.edu/resources/res_display.asp?RecordID=300 (accessed March 2021).

Mendelsohn RO, Morrison WN, Schlesinger ME, Andronova NG (2000). Country-specific market impacts of climate change. Climatic Change 45(3-4): 553-569. MOSEK (2004). MOSEK product information. Available at: https://www.mosek.com/ (accessed March, 2021).

Mu, J. E., McCarl, B. A., \& Wein, A. M. (2013). Adaptation to climate change: Changes in farmland use and stocking rate in the U.S. Mitigation and Adaptation Strategies for Global Change, 18(6), 713-730. https://doi.org/10.1007/s11027-012-9384-4

NBFPC (2016). Stumpage study results - October 2015 to September 2016. New Brunswick Forest Products Commission. Fredericton, NB.

Nordhaus WD (1991). To Slow or Not to Slow: The Economics of the Greenhouse Effect. Economic Journal 101(444): $920-937$.

NRCan (2020). Statistical Data. Natural Resources Canada. Available at: https://cfs.nrcan.gc.ca/statsprofile/economicimpact/NB (accessed: March 1, 2021).

Ochuodho TO, Lantz VA, Olale E (2016). Economic impacts of climate change considering individual, additive, and simultaneous changes in forest and agriculture sectors in Canada: A dynamic, multi-regional CGE model analysis. Forest Policy and Economics, 63, 43-51.

Ochuodho TO, Lantz VA (2014). Economic impacts of climate change in the forest sector: A comparison of single-region and multiregional CGE modeling frameworks. Canadian Journal of Forest Research, 44(5), 449-464.

Ochuodho TO, Lantz VA, Lloyd-Smith P, Benitez P (2012). Regional economic impacts of climate change and adaptation in Canadian forests: A CGE modeling analysis. Forest Policy and Economics, 25, 100-112.

Perez-Garcia J, Joyce LA, Binkley CS, McGuire AD (1997). Economic impacts of climate change on the global forest sector: an integrated ecological/economic assessment. Critical Reviews in Environmental Science and Technology 27: 123-138.

Perez-Garcia J, Joyce LA, McGuire AD, Xiao X (2002). Impacts of climate change on the global forest sector. Climatic Change 54: $439-461$.

Remsoft (1997). Woodstock forest management software. Remsoft Inc. Available at: https://remsoft.com/woodstock-optimization-studio/ (last accessed Feb 1, 2021).

Sohngen B, Sedjo R (2005). Impacts of climate change on forest product markets: implications for North American producers. Forestry Chronicle 81(5): 669674.

Sohngen B, Mendelsohn R, Sedjo R (2001). A global model of climate change impacts on timber markets. Journal of Agricultural and Resource Economics 26 (2): $326-343$.

Statistics Canada (2020). Projected population, by projection scenario, sex and age group as of July 1, Canada, provinces and territories, annual (persons). Retrieved March 12, 2021 from: https://www150.statcan.gc.ca/t1/tbl1/en/tv.action?

pid $=1710005701 \&$ pickMembers\%5B0\%5D =1.5\&pickMembers\%5B1\%5D =3.1\&pickMembers\%5B2\%5D=4.1\&cubeTimeFrame.startYear=2021\&cubeTimeFrame.

Statistics Canada (2015a). Provincial symmetric input-output tables. Statistics Canada. Available at: https://www150.statcan.gc.ca/n1/en/catalogue/15-211X (accessed: April 4 2021).

Statistics Canada (2015b). New Brunswick's Supply and use table. Available at https://www150.statcan.gc.ca/n1/pub/15-602-x/2017001/xlsx/15-602x_2015_eng.zip (accessed: April 4 2021).

Taylor A, Boulanger Y, Price D, Cyr D, McGarrigle E, Rammer W, Kershaw J (2017). Rapid 21st century climate change projected to shift composition and growth of Canada's Acadian Forest Region. Forest Ecology and Management 405: 284-294.

Vaughan W, Taylor A, MacLean DA, D'Orangeville L, Lavigne M (2021). Climate change experiment suggests divergent responses of tree seedlings in eastern North America's Acadian Forest Region over the 21st century. Canadian Journal of Forest Research (in press: https://doi.org/10.1139/cjfr-2021-0047)

Walters KR (1993). Design and development of a generalised forest management system: Woodstock, in International Symposium on Systems Analysis and Management Decisions in Forestry (Valdivia: Remsoft Inc.).

Williamson T, Colombo S, Duinker P, Gray P, Hennessey R, Houle D, Johnston M, Ogden A, Spittlehouse D (2009). Climate change and Canada's forests: from impacts to adaptation. Natural Resources Canada, Canadian Forest Service, Northern Forestry Centre, Edmonton, Alberta. 104 p.

Williamson TB, Price DT, Beverly JL, Bothwell PM, Frenkel B, Park J, Patriquin MN (2008). Assessing potential biophysical and socioeconomic impacts of climate change on forest-based communities: a methodological case study. Natural Resources Canada, Canadian Forest Service, Northern Forestry Centre, Edmonton, Alberta. Information Report NOR-X-415E.

World Bank (2020). Doing Business 2020 (Vol. 6, Issue 6). https://doi.org/10.1596/978-1-4648-1440-2 (accessed: April 4 2018). 
Zhang J, Alavalapati JRR, Shrestha RK, Hodges AW (2005). Economic impacts of closing national forests for commercial timber production in Florida and Liberty County. Journal of Forest Economics 10: 207-223.

\section{Tables}

Table 1: Production sectors included in the CGE model

\begin{tabular}{|c|c|c|c|}
\hline sec1 & Crop and animal production (CROP) & $\sec 15$ & Other manufacturing (O-MANUF) \\
\hline sec2 & Softwood forestry \& logging (S-FOR) & $\sec 16$ & Wholesale Trade (WT) \\
\hline sec3 & Hardwood forestry \& logging (H-FOR) & $\sec 17$ & Retail trade $(\mathrm{RT})$ \\
\hline $\sec 4$ & Fishing, hunting and trapping (FISH) & $\sec 18$ & Transportation \& warehousing (TRANSP) \\
\hline $\sec 5$ & Support activities for agric/for (SUPP) & $\sec 19$ & Information \& cultural industries (INFO) \\
\hline sec6 & Mining, oil, and gas extraction (MIN) & $\sec 20$ & Finance, insurance, real estate (FIN) \\
\hline $\sec 7$ & Utilities (UTIL) & $\sec 21$ & Professional, scientific, tech services (PROF) \\
\hline sec8 & Construction (CONST) & $\sec 22$ & Admin support, waste mngt, etc. (ADMIN) \\
\hline $\sec 9$ & Sawmills \& wood preservation (SAW-MANUF) & $\sec 23$ & Education services (EDU) \\
\hline $\sec 10$ & Veneer plywood \& eng wood (VEN-MANUF) & $\sec 24$ & Healthcare \& social assistance (HEALTH) \\
\hline $\sec 11$ & Other wood product manuf (OW-MANUF) & $\sec 25$ & Arts, entertainment, education (ARTS) \\
\hline $\sec 12$ & Pulp, paper \& cardboard mills (PULP-MANUF) & $\sec 26$ & Accommodation \& food services (ACC) \\
\hline $\sec 13$ & Converted paper product manuf (CP-MANUF) & $\sec 27$ & Other services (OTHER) \\
\hline $\sec 14$ & Printing \& support activities (PR-MANUF) & & \\
\hline
\end{tabular}

Table 2. Comparison of Crown and private forest land in New Brunswick

\begin{tabular}{|lll|}
\hline & Crown forest & Private forest \\
\hline Forest land area (mill ha) $^{\mathrm{a}}$ & 3.1 & 2.9 \\
\hline SW Harvest (mill m $\left.{ }^{3}, 2019\right)^{\mathrm{a}}$ & 3.5 & 2.7 \\
\hline HW Harvest (mill m $\left.^{3}, 2019\right)^{\mathrm{a}}$ & 2.1 & 1.1 \\
\hline SW dominated growing stock (mill m³) & 156 & $?^{\mathrm{d}}$ \\
\hline HW dominated growing stock $\left(\mathrm{mill} \mathrm{m}^{3}\right)^{\mathrm{b}}$ & 90 & $?^{\mathrm{d}}$ \\
\hline Area in SW Plantations ('000 ha) & 454 & 55 \\
\hline SW Planting (mill seedlings/yr, 2019) & 20.1 & 2.8 \\
\hline
\end{tabular}

${ }^{\text {a }}$ NRCan (2020).

${ }^{\mathrm{b}}$ CCFM (2005).

${ }^{\mathrm{c}}$ C. Hennigar, ERD, personal communication, 2021. The private forest plantation and planting estimates exclude freehold areas (representing $18 \%$ of NB forest land).

${ }^{\mathrm{d}}$ Data not available.

Table 3. Sectoral output quantity (measured at 2015 prices) by scenario in 2095

(in \% difference from Baseline) ${ }^{a}$ 


\begin{tabular}{|c|c|c|c|c|}
\hline & Scenarios & & & \\
\hline Sector ${ }^{\mathrm{a}}$ & $\begin{array}{l}\text { Baseline } \\
\text { (\$ millions) }\end{array}$ & $\begin{array}{l}\text { Scenario } 2 \\
\text { (\% diff) }\end{array}$ & $\begin{array}{l}\text { Scenario } 3 \\
\text { (\% diff) }\end{array}$ & $\begin{array}{l}\text { Scenario } 4 \\
\text { (\% diff) }\end{array}$ \\
\hline CROP & 846.0 & $2.67 \%$ & $0.21 \%$ & $0.01 \%$ \\
\hline S-FOR & 475.1 & $-12.94 \%$ & $-1.50 \%$ & $-2.16 \%$ \\
\hline H-FOR & 192.3 & $-7.20 \%$ & $-0.06 \%$ & $2.35 \%$ \\
\hline FISH & 368.7 & $4.02 \%$ & $0.33 \%$ & $0.04 \%$ \\
\hline SUPP & 88.6 & $-8.32 \%$ & $-0.68 \%$ & $-0.11 \%$ \\
\hline OILGAS & 714.5 & $3.82 \%$ & $0.31 \%$ & $0.02 \%$ \\
\hline UTL & 1551.7 & $-0.87 \%$ & $-0.05 \%$ & $0.10 \%$ \\
\hline CONST & 4260.0 & $-0.50 \%$ & $-0.05 \%$ & $-0.03 \%$ \\
\hline SAW-MANUF & 886.2 & $-13.29 \%$ & $-1.51 \%$ & $-2.11 \%$ \\
\hline VEN-MANUF & 202.5 & $-29.34 \%$ & $-5.21 \%$ & $-11.78 \%$ \\
\hline OW-MANUF & 186.1 & $-11.21 \%$ & $-1.76 \%$ & $-4.04 \%$ \\
\hline PUP-MANUF & 1423.3 & $-7.45 \%$ & $-0.03 \%$ & $2.49 \%$ \\
\hline CP-MANUF & 495.8 & $-8.33 \%$ & $-0.02 \%$ & $2.85 \%$ \\
\hline PR-MANUF & 24.6 & $-0.09 \%$ & $0.05 \%$ & $0.23 \%$ \\
\hline OTH-MANUF & 14717.6 & $3.49 \%$ & $0.28 \%$ & $0.02 \%$ \\
\hline TRADES & 1693.6 & $0.39 \%$ & $0.03 \%$ & $-0.01 \%$ \\
\hline RET & 3124.3 & $-0.32 \%$ & $-0.03 \%$ & $-0.02 \%$ \\
\hline TRANSP & 3870.6 & $-1.58 \%$ & $-0.10 \%$ & $0.11 \%$ \\
\hline INFO & 1414.8 & $-0.16 \%$ & $-0.01 \%$ & $-0.01 \%$ \\
\hline FIN & 8309.8 & $-0.34 \%$ & $-0.03 \%$ & $-0.01 \%$ \\
\hline PROF & 1526.8 & $-0.24 \%$ & $-0.02 \%$ & $0.00 \%$ \\
\hline ADMIN & 2091.4 & $-1.02 \%$ & $-0.08 \%$ & $0.01 \%$ \\
\hline EDUC & 139.3 & $-0.48 \%$ & $-0.04 \%$ & $-0.01 \%$ \\
\hline HEALTH & 1405.6 & $-0.31 \%$ & $-0.03 \%$ & $-0.02 \%$ \\
\hline ENT & 373.2 & $-0.59 \%$ & $-0.05 \%$ & $-0.01 \%$ \\
\hline ACC & 1479.6 & $-0.40 \%$ & $-0.03 \%$ & $-0.01 \%$ \\
\hline OG\&S & 1343.3 & $-0.42 \%$ & $-0.03 \%$ & $-0.01 \%$ \\
\hline
\end{tabular}

a See Table 1 for sector descriptions.

Table 4. Sectoral output prices by scenario in 2095 (in \% difference from Baseline $\left.{ }^{a}\right)^{b}$ 


\begin{tabular}{|c|c|c|c|}
\hline & Scenarios & & \\
\hline Sector & $\begin{array}{l}\text { Scenario } 2 \\
\text { (\% diff) }\end{array}$ & $\begin{array}{l}\text { Scenario } 3 \\
\text { (\% diff) }\end{array}$ & $\begin{array}{l}\text { Scenario } 4 \\
\text { (\% diff) }\end{array}$ \\
\hline CROP & $0.21 \%$ & $0.02 \%$ & $0.01 \%$ \\
\hline S-FOR & $5.44 \%$ & $0.74 \%$ & $1.59 \%$ \\
\hline H-FOR & $-1.01 \%$ & $-0.71 \%$ & $-2.98 \%$ \\
\hline $\mathrm{FISH}$ & $0.11 \%$ & $0.01 \%$ & $0.00 \%$ \\
\hline SUPP & $0.12 \%$ & $0.01 \%$ & $0.01 \%$ \\
\hline OILGAS & $0.18 \%$ & $0.02 \%$ & $0.01 \%$ \\
\hline UTL & $0.21 \%$ & $0.02 \%$ & $0.01 \%$ \\
\hline CONST & $0.27 \%$ & $0.03 \%$ & $0.04 \%$ \\
\hline SAW-MANUF & $2.35 \%$ & $0.30 \%$ & $0.58 \%$ \\
\hline VEN-MANUF & $1.45 \%$ & $0.19 \%$ & $0.37 \%$ \\
\hline OW-MANUF & $1.36 \%$ & $0.18 \%$ & $0.36 \%$ \\
\hline PUP-MANUF & $0.92 \%$ & $0.05 \%$ & $-0.11 \%$ \\
\hline CP-MANUF & $1.13 \%$ & $0.04 \%$ & $-0.20 \%$ \\
\hline PR-MANUF & $0.38 \%$ & $0.02 \%$ & $-0.04 \%$ \\
\hline OTH-MANUF & $0.32 \%$ & $0.03 \%$ & $0.01 \%$ \\
\hline TRADES & $0.13 \%$ & $0.01 \%$ & $0.01 \%$ \\
\hline RET & $0.11 \%$ & $0.01 \%$ & $0.01 \%$ \\
\hline TRANSP & $0.13 \%$ & $0.01 \%$ & $0.01 \%$ \\
\hline INFO & $0.17 \%$ & $0.02 \%$ & $0.01 \%$ \\
\hline FIN & $0.11 \%$ & $0.01 \%$ & $0.01 \%$ \\
\hline PROF & $0.09 \%$ & $0.01 \%$ & $0.00 \%$ \\
\hline ADMIN & $0.10 \%$ & $0.01 \%$ & $0.01 \%$ \\
\hline EDUC & $0.09 \%$ & $0.01 \%$ & $0.01 \%$ \\
\hline HEALTH & $0.12 \%$ & $0.01 \%$ & $0.01 \%$ \\
\hline ENT & $0.12 \%$ & $0.01 \%$ & $0.01 \%$ \\
\hline ACC & $0.16 \%$ & $0.01 \%$ & $0.01 \%$ \\
\hline OG\&S & $0.11 \%$ & $0.01 \%$ & $0.00 \%$ \\
\hline
\end{tabular}

a Baseline prices are normalized to 1.

${ }^{\mathrm{b}}$ See Table 1 for sector descriptions.

Table 5. Macro-economic variables by scenario in 2095 


\begin{tabular}{lllll} 
Variables & $\begin{array}{l}\text { Baseline } \\
\text { (\$ mill) }\end{array}$ & $\begin{array}{l}\text { Scenario 2 } \\
\text { (\% diff) }\end{array}$ & $\begin{array}{l}\text { Scenario 3 } \\
\text { (\% diff) }\end{array}$ & $\begin{array}{l}\text { Scenario 4 } \\
\text { (\% diff) }\end{array}$ \\
\hline GDP & 29973 & $-0.33 \%$ & -0.03 & $-0.01 \%$ \\
\hline EV & 453 & $-9.00 \%$ & $-0.75 \%$ & $-0.24 \%$ \\
\hline Y & 30233 & $-0.13 \%$ & $-0.01 \%$ & $0.00 \%$ \\
\hline C & 20955 & $-0.13 \%$ & $-0.01 \%$ & $0.00 \%$ \\
\hline G & 11060 & $-0.25 \%$ & $-0.02 \%$ & $-0.02 \%$ \\
\hline I & 3037 & $0.02 \%$ & $0.00 \%$ & $0.00 \%$ \\
\hline L & 17562 & $-0.42 \%$ & $-0.04 \%$ & $-0.02 \%$ \\
\hline K & 9468 & $-0.07 \%$ & $-0.01 \%$ & $0.00 \%$ \\
\hline IMP & 29053 & $1.31 \%$ & $0.11 \%$ & $0.03 \%$ \\
\hline EXP & 23983 & $1.41 \%$ & $0.12 \%$ & $0.04 \%$ \\
\hline XD & 53205 & $-0.043 \%$ & $0.00 \%$ & $0.00 \%$ \\
\hline XDD & 28507 & $-0.35 \%$ & $-0.02 \%$ & $0.02 \%$
\end{tabular}

${ }^{\text {a }} \mathrm{GDP}=$ gross domestic product; $\mathrm{EV}=$ equivalent variation; $\mathrm{Y}=$ income; $\mathrm{C}=$ consumption; $\mathrm{G}=$ government; $\mathrm{I}=\mathrm{Investment} ; \mathrm{IMP}=$ imports; $\mathrm{EXP}=$ exports; $\mathrm{XD}=$ output consumed by the domestic market (includes imports), XDD = output produced and consumed domestically.

Table 6. Cumulative present value macro-economic variables by scenario

(2015-95, 2\% discount rate)

\begin{tabular}{lllll} 
Variables & $\begin{array}{l}\text { Baseline } \\
\text { (\$ mill) }\end{array}$ & $\begin{array}{l}\text { Scenario 2 } \\
\text { (\% diff) }\end{array}$ & $\begin{array}{l}\text { Scenario 3 } \\
\text { (\% diff) }\end{array}$ & $\begin{array}{l}\text { Scenario 4 } \\
\text { (\% diff) }\end{array}$ \\
\hline GDP & 255120 & $-0.08 \%$ & $0.00 \%$ & $-0.02 \%$ \\
\hline EV & 1397 & $-6.22 \%$ & $-0.29 \%$ & $-1.09 \%$ \\
\hline Y & 258615 & $-0.03 \%$ & $0.00 \%$ & $-0.01 \%$ \\
\hline C & 179253 & $-0.03 \%$ & $0.00 \%$ & $-0.01 \%$ \\
\hline G & 93906 & $-0.6 \%$ & $0.00 \%$ & $-0.01 \%$ \\
\hline I & 25978 & $0.01 \%$ & $0.00 \%$ & $0.00 \%$ \\
\hline L & 149717 & $-0.11 \%$ & $-0.01 \%$ & $-0.02 \%$ \\
\hline K & 80572 & $-0.02 \%$ & $0.00 \%$ & $0.00 \%$ \\
\hline IMP & 248905 & $0.33 \%$ & $0.02 \%$ & $0.06 \%$ \\
\hline EXP & 204889 & $0.35 \%$ & $0.02 \%$ & $0.06 \%$ \\
\hline XD & 450271 & $-0.011 \%$ & $0.00 \%$ & $0.00 \%$ \\
\hline XDD & 243163 & $-0.09 \%$ & $0.00 \%$ & $-0.01 \%$
\end{tabular}

a GDP = gross domestic product; $\mathrm{EV}=$ equivalent variation; $\mathrm{Y}=$ income; $\mathrm{C}=$ consumption; $\mathrm{G}=$ government; I = Investment; IMP = imports; $\mathrm{EXP}=$ exports; $\mathrm{XD}=$ output consumed by the domestic market (includes imports), XDD = output produced within the domestic market and consumed domestically.

Table 7. Cost-benefit analysis of planting drought resistant softwood seedlings 
Cost Components:

- Additional office, lab, greenhouse space for growing field trials, and related infrastructure (\$, one-time)

- R\&D activities to develop drought tolerance breeding strategy (\$, spread over first 5 years)

- Salaries, benefits, vehicles, and related costs for additional tree improvement professionals and technicians $(\$ / y r)$

- Maintenance and up-keep for the additional office, lab, and related infrastructure $(\$ / y r)$

- Additional materials \& supplies (herbicide, field tags, data recorders, greenhouse supplies, etc. (\$/yr)

- Additional contract work for incremental test sites including mechanical site prep, weed control, etc. (\$/yr)

Total present value costs ${ }^{a}$

Total present value benefits ${ }^{a, b}$

Benefit-cost ratio ${ }^{a}$

Net present value ${ }^{\mathrm{a}}$

a Using a discount rate of $2 \%$.

${ }^{b}$ Using the present value equivalent variation estimate from the CGE model analysis in Table 6.

Table 8. Cost-benefit analysis of planting hardwoods in place of failed spruce plantations

Cost Components:

- R\&D activities to develop hardwood silviculture program (program leader, research staff, field studies, data analysis, and reporting (\$, spread over first 5 years)

- Incremental seedling cost $(\$ / y r)$

- Incremental Planting cost $(\$ / y r)$

- Incremental Silviculture cost $(\$ / y r)$

Total present value costs ${ }^{a}$

Total present value benefits ${ }^{a, b}$

Benefit-cost ratio $^{a}$

a Using a discount rate of $2 \%$

${ }^{b}$ Using the present value equivalent variation estimate from the CGE model analysis in Table 6.

\section{Figures}




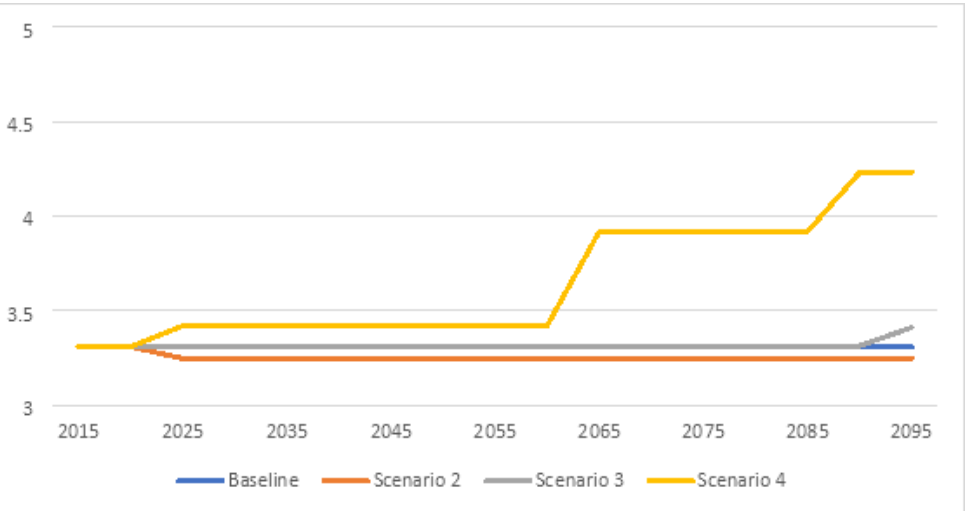

Figure 1

Hardwood timber supply ( $\mathrm{m}^{\wedge} 3$ mill)

\section{Figure 2}

Softwood timber supply ( $\mathrm{m}^{\wedge} 3$ mill)

\section{Figure 3}

Hardwood stumpage price (\$nominalized, relative to 2015)

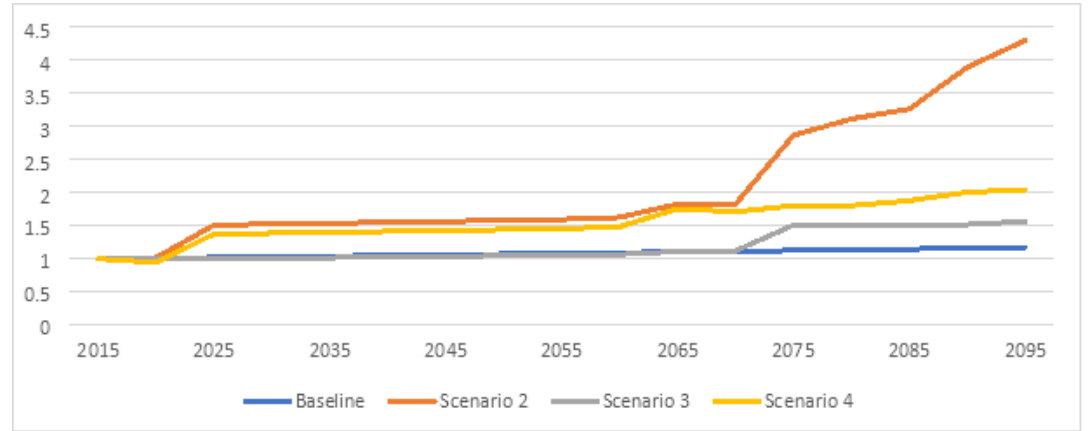

Figure 4

Softwood stumpage price (\$nominalized, relative to 2015)

\section{Supplementary Files}

This is a list of supplementary files associated with this preprint. Click to download.

- AppendixLantz.docx 